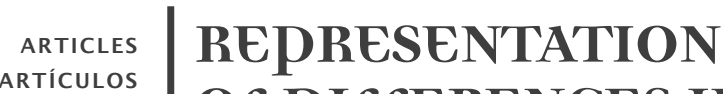 OF DIFFERENCES IN BRAZILIAN JOURNALISTIC DISCOURSE \\ Copyright @ 2014 \\ FERNANDO RESENDE \\ Universidade Federal Fluminense, Brazil
} SBPjor / Associação Brasileira de Pesquisadores em Jornalismo

\begin{abstract}
Considering the technological advance, which enhances the production of mediatic discourses, and the notion of a libidinal power installed in our globalized societies, reflecting upon representation of differences seems to be a major issue. This essay discusses the production of journalistic discourses from an epistemological perspective. The field of media is taken as constituted by a triple component - discourse/narrative/machines - and we suggest that this triad has proved to be incomplete: discourse and narrative, once they really are vertexes of the triangle, are absences. Two journalistic-documentary productions - which intend to represent life in the slums of Brazil - are compared in order to reflect upon representation of differences in Brazilian journalistic discourse. In view of the up-to-date polarization and pulverization of discourses, we suggest that in the perspective of the journalistic discourse, one can only speak about alterity if one tries to comprehend the ways news is staged.

Keywords: Journalism. Discourse. Documentary. Culture. Representation.
\end{abstract}

\section{REPRESENTAÇÃO DAS DIFERENÇAS NO DISCURSO JORNALÍSTICO}

RESUMO - Considerando o avanço tecnológico, que potencializa a produção dos discursos midiáticos, e a noção de um poder libidinal instalado em nossas sociedades globalizadas, refletir sobre a representação das diferenças parece ser a principal questão. Este ensaio discute a produção de discursos jornalísticos de uma perspectiva epistemológica. O campo da mídia é compreendido como constituído por três componentes - discurso/ narrativa/ máquinas -, e sugerimos que esta tríade já provou ser incompleta: o discurso e a narrativa, uma vez que são de fato vértices do triângulo, são ausências. Dois documentários - que pretendem representar a vida em favelas no Brasil - são comparados com o objetivo de refletir sobre a representação das diferenças no discurso jornalístico brasileiro. Tendo em vista a polarização e a pulverização dos discursos, concluímos que, na perspectiva do discurso jornalístico, só se pode falar sobre alteridade se for possível compreender como as notícias são encenadas.

Palavras-chave: Jornalismo. Discurso. Documental. Cultura. Representação

\section{REPRESENTACIÓN DE LAS DIFERENCIAS EN EL DISCURSO PERIODÍSTICO}

RESUMEN - Actualmente, al considerar la relevancia del avance tecnológico en el proceso de recuperación de la producción de los discursos mediáticos, la cuestión de la representación de las diferencias surge como tema central. Ante la diversidad de medios a través de los que se pueden narrar los acontecimientos, la comunicación social, y en particular el periodismo, asume un papel preponderante: es un lugar más desde donde se conforma la vida del otro. El periódico Folha de S. Paulo publicó el día 26 de marzo de 2006 varios artículos sobre los productos de los medios de comunicación que tienen como temática los dilemas de las favelas en Brasil. Se trata de productos mediáticos variados, cuyo contenido gira en torno a este problema. La presentación de un documental, Falcão - Meninos do tráfico (Halcón, los niños del narcotráfico), además de reavivar la discusión sobre el tema que aborda, nos auxilia a conducir esta reflexión. Palabras clave: Periodismo. Discurso. Documental. Cultura. Representación. 
Nowadays, considering the relevance of the technological advance in the process of intensification of mediatic discourse production, the issue of the representation of differences constitutes a central subject. In face of the diversity of ways in which one is able to narrate events, social communication, and particularly journalism, one assumes a preponderant role. It is another place from which one plots the life of the other. The newspaper Folha de S. Paulo' on May 26, 2006 presented several articles about the media products that have the dilemmas of Brazilian slums ${ }^{2}$ as their subject matter. There is a variety of media products in which the contents focus on this problem and the presentation of the documentary film Falcão - os meninos do tráfico ${ }^{3}$, besides renewing the discussion of the theme it dealt with, helps us to develop this reflection.

Displayed and exhaustively announced by the TV show Fantástico, on May 19, 2006, the documentary was directed by rapper MV Bill who during the interviews described himself as a legitimate person to speak about that place, since he was born and raised in the slums. On presenting what he considered as the reality of the minors who worked as "watchmen" on the hills, MV Bill believed he was capable of mobilizing the nation in a distinct manner with the images he produced. And TV Globo, which announced a one-hour interruption in its Sunday program schedule, seemed to agree with MV Bill, since it affirmed that we would have access, on that Sunday, to images of drug dealing and slums never seen before.

Indeed the images caused a tremendous impact. On the following day, the comments of those who watched the film basically presented two approaches: while some of them appeared to be shocked by what they had seen, others assumed a posture of indifference, because they claimed that they already knew about that situation; since they were bombarded with news and images about the same theme on a daily basis. The reaction of the first group seemed to point out how the panic they had felt attained its materialization in the images of children or youngsters who, with their faces covered by a black strip, revealed the toughness and cruelty involved in making a living from drug dealing. The other group, on the other hand, seemed to tell us that there was nothing new in those images, since they were about something that had already been seen and shown in 
many other places. The impact caused by the transmission of that documentary in the television scenario also revealed something that was not at all new: helpless in face of a reality so far from what we are and desire to be, we always end up either doomed to panic or to becoming indifferent.

According to anthropologist Alba Zaluar, the repercussion of Falcão - os meninos do tráfico has "proven once again the greater communication power that television has in relation to the other media, not only due to its capability to penetrate into so many homes, but also due to the strength of the images associated with the voice and the text of what is said" (Folha de S. Paulo, 26/02/2006). The event as it appears to be brings to surface the power of the technical images, which besides leading us to search the facts for the truth they seem to reveal, make, for example, the film director, for reasons associated with his own life experience, appear to be the possessor of a legitimate discourse. Therefore, by making us focus on "the voice and the text of what is said", we always rely on the object of the discourse - strictly speaking, on the theme - while we more and more lose our focus on the ways the news are staged, of the discourse within the object.

With respect, for instance, to the discourse of another documentary film, Notícias de uma guerra particular- also with a journalistic nature and in which the proposition is to represent ways of life and characters related to the drug business in Brazilian slums - we perceive that one of the narrative strategies that marks it is the panoramic view of the city of Rio de Janeiro, an urban space that includes, with its contradictions, the slum and the "asphalt". At various times throughout this narrative structure we are taken by the camera to see from above a maze of lights, houses, buildings, cars and streets that, from our perspective, bring out the diversity of lives and paths to be discovered. The image we see is the same one Michel de Certeau (2000) reflects on when discussing the issues concerning the city and its passers-by: seen from above, according to the author, we understand that the complex dimension that dwells in our city belongs to the traces made by its pedestrians; in other words, every city only takes shape when the pedestrians trace their ways on it.

In Notícias..., the landscape unfolded before us is soon intersected by others that reveal the slum's labyrinth, allowing us to see faces and places full of the contradictions and paradoxes that 
delineate the urban space they live in. This view of the micro is not disconnected from the macro that surrounds it, since what we see throughout the labyrinths - children playing, guns and drugs in the hands of the drug dealers, pedestrians treading dirty streets - is constitutive of it. Soon we realize the news we are having access to is about not only a particular war, but also a particular event that affects everyone.

Besides the possible effects caused by the presentation of these documentaries, this article, by comparing the narrative structures of Falcão... and Notícias..., argues that for present-day journalism, an analysis that now pursues the knowledge of the ways the facts are narrated is paramount. We believe therefore that it is in the process of narrative construction - in the ways the news is staged - that one can reveal and evaluate some of the mechanisms for producing the differences that, according to Castro-Gómez (2000), are one of the challenges of the critical theory in contemporary societies. From this perspective, we take as a reference some of the strategies that have legitimated the journalistic discourse in Brazil, aiming not only at discussing the problems of a discourse that rarely faces the challenge of a dialogue with the other, but also at reflecting upon the production of knowledge about this same discourse.

\section{THE “I” AND THE OTHER IN THE DYNAMICS OF REPRESENTATION}

Journalism studies in Brazil, which in recent years have concentrated their questions on the perspective of content, on what the news contains and means, for example, used to present as a basic issue the desire to understand and explain journalism. An absolutely necessary approach, considering the inaugural space of a field constituted mostly on the basis of a practice a proceeding lacking in reflection - rather than a praxis. This practice - essential and urgent as the illuminist approach tried to find spaces to express its desire to clarify and explain the facts of the world - by accepting its establishment as a field of knowledge, helped journalism be invested with the need of self-explanation, a fact that arose according to what one conceives as its raw material, the information, and to the function attributed to it: showing to society what is happening. 
Therefore, we would have to understand journalism not from the perspective of what this specific field offers as a complex arrangement, but from the aseptic propositions that in the field of communication as a whole used to regard any noise as an undesirable matter, since such noise would only make its practice less effective in complying with its attributions, which in journalism would be, summarily, to show, clarify and explain the facts of the daily routine. In the bulk of these studies ${ }^{4}$, we look for answers to what journalism should be, discussing ethical issues - what the posture and the role of a journalist should be, for example - and the relevance of this entity that legitimized itself as the place in which the facts would be revealed, as if the act of bringing the facts to the surface itself would not contain the complexity one tried to avoid.

From this point of view, and also because in this field one deals with what is immediate, our studies and practices are devoted to creating ways to enable us to speak about the micro using objectivity as a strategic ritual (Tuchman, 1999) and separating related genres - informative and opinionative, for example - to avoid possible incoherence present in any discursive order. One should understand that nowadays since the machines themselves allow us to use countless ways to narrate the daily routine - our private little wars - this way of speaking, previously legitimated by the discourse regarding journalism, is far from facing a challenge which we believe is central: moving closer to the other. In this sense, the narrative structure that we find in Falcão... is elucidative.

In this documentary's opening we perceive at once that the theme will be dealt with from a reductionist point of view, either because we will see it from the perspective of the one who "trims" it - MV Bill, its author - or because the fact will be taken as if it were not part of a spatiality that adds to its complexity. In Falcão..., we see the slum framed through the window of a car on which MV Bill is sitting, and he is the one who speaks about and explains that place. We do not enter there to discover what is hidden in the city's labyrinths, but to know how life in the slum is. The didactic explanatory manner of speaking in the author's discourse and in the various following testimonies, even though coherent with the director's propositions - as he says he knows what to show - is 
revealing, above all, the problematic relation between the "I" and the other in the representation's perspective.

One of the ethical dilemmas that are encountered not only in the production of documentaries, but also in every object that engages in the function of speaking about the other, refers to ways of representing the other in the latter's difference ${ }^{5}$. Therefore, if we care for how to enable the other to be seen apart from what our eyes recognize as "familiar", it seems fundamental for us to understand that, according to a record, filmic or any other discursive order, the view, reduced to a didactic and/or opinionative dimension the same that places journalism in an illuminist and conductive epistemology (RESENDE, 2002) - is insufficient. Regarding Falcão..., for example, from which is provided to be seen, what stands out is the total lack of perspective and possibility of relation: in face of the incoherence of what I see, I end up being absolutely powerless. According to newspaper critic Amir Labaki, "the interviewees [in Falcão...] are depersonalized by black strips covering their eyes or a blurring effect on their faces, without identity except for their association with crime and violence". And the audience, Labaki says, "saw a stretched-out sensationalistic report, devoid of any factual novelty".

\section{JOURNALISM: ENUNCIATION AND WILL TO TRUTH}

The field of the media undergoes a process of correlating forces with various social fields - political, economic, cultural and religious, among others - since it becomes a structural element for the constitution and composition of these spaces. Considering the fact journalism, more specifically, is charged with the task of speaking about and to other social instances, we have to consider that one of the possible places where the correlation of forces is established, with all of its asymmetries and fragmentations, is the field of discourse. A fundamental instance for reflecting on the representation issue is now when the altered notions of space and time reconfigure the roles and pertinences either in the fields or in the social actors that constitute society and with which the mediatic products invariably dialogue (RESENDE, 2003).

From this point of view, the question of the representation of differences, in the perspective of journalistic products, establishes an intrinsic relation with the enunciation issue. For 
Benveniste (1995), the issue concerning the speaking subject and the subject of the utterance is in the center of the reflection, which means what the speaker is in relation to the receiver, what the $\mathrm{I}$ is in relation to the You; the author sets out from the distinction between l'énoncé (the enunciated), already uttered, and l'énonciation (the enunciation), the action that produces the utterance. Benveniste focuses on the way by which an individual marks himself by what he says, establishing in this manner what is conventionally called the "theorie de l'énonciation" (theory of enunciation). The author affirms: "Language is possible only because each speaker sets himself up as a subject by referring to himself as I in his discourse. (...) This polarity of persons is the fundamental condition in language" (1995: 286-7). In this same theoretical perspective, although in a distinct direction, Bakhtin (1979) demonstrates that the enunciation is a social phenomenon rather than an individual one, determined by a historical context that leads to the constitution of subjectivity itself; another aspect we believe to be relevant when dealing with the reflection concerning journalistic enunciation.

The reference to Foucault (1996) also seems fundamental, as we understand that the gesture of addressing a discourse implies what the author calls "the will to truth".

By working with the three procedures of exclusion in which the discourse's production operates (interdiction, segregation and the will to truth), Foucault makes explicit the means by which the place of the speaking subject is legitimatized, establishing these means as based on social conditions in which the discourses operate and are uttered.

Taking the third procedure - the will to truth - as a centralizer, because at the same time it reformulates and legitimates the other two, the author helps us to think about the field of media and therefore about the places of discourse as what legitimate our will to truth. If for Foucault, societies of knowledge were previously the instances that legitimated a discourse intended to be truthful, we are likely to suppose that the media, with their institutional support and through their objects that produce discourses, constitute a fundamental instance because they operate as regulators and upholders of a status quo that aims to order the facts which compose our social relations.

This means that the field of journalism is given the task of 
producing knowledge about world events, a task that is conferred upon it either because it holds the technology - an incommensurable machine power - or because other knowledge-producing institutions - with pedagogical character - grant the right of speech to the media discourse. From these places, through will and power, covered by the will to truth, journalistic discourses become maximum expressions of what is truthful; and it is with them, it should be said, that we shape our ways of understanding and seeing the world, views that compose our perception of the other and our way of dealing with the different or the similar.

Foucault also alerts us to the fact that the procedure of segregation, though rather weakened, does not necessarily undergo a rupture, since as the author says, "(...) it is always through maintaining censorship that the hearing is fulfilled" (1996: 13). In other words, in the field of media, this condition is confirmed: the other, once under the condition of speaking, always speaks from a non-place, because he invariably speaks through whom concedes him this right, a condition of authority, rather than a practice of othering. And it is this procedure, it should be mentioned, that reiterates the first one, interdiction, the indicator "that one does not have the right to say everything, that one cannot speak everything at every opportunity, that, finally, not just anyone can talk about just anything" (FOUCAULT, 1996:09).

Therefore, a vicious circle is configured in the field of the media and the idea that truth is to be found in what the discourse says, never in what it does or even in what it is, emerges. The individual who speaks and from where he speaks are absolutely relevant criteria and definers of what happens to be the true or not. We believe or pretend to believe in the idea that truth is there, either because the place of the event's representation is institutionally legitimated or because the one who utters the discourse, in the empirical figure of the individual who speaks, has credibility; even though sometimes we could question him, it can be said, for reasons almost always ideological. In this sense, following Foucault's reflection, questioning and doubting the will to truth is essential. 


\section{POLARIZATION AND PULVERIZATION OF DISCOURSES}

As an example, we mention the following situation: at the time of Iraq's invasion in 2003, several media - press, television and others - either reported the event from the perspective of the invaders or, as the media claimed, from the point of view of the invaded. The embedded journalists, who accompanied the military forces in order to relate the facts more accurately ended up revealing how fragile are the discourses sustained by indicative information, those based on the will to truth as the primary conditioning factor ${ }^{5}$. A more attentive look at CNN's reports - a North-American media enterprise that at the time sold and spread official news worldwide about what they called "war against the evil" - leads us to perceive that the expressions were exclusively what the invader nation wanted people to believe. When Al Jazeera - Arabian tv broadcast that identified itself as more apt to behold and report facts under the view point of the invaded entered the scene, doubtlessly a landmark in the contemporary media scenario, it polarized the discourses: since the war was against evil, evil was willing to speak.

This process of polarization of discourses, an example of ways of conflict manifestation in the media area, does not present as a novelty the fact that each one, on each side, has something to say, for this aspect is already known ever since man seeks means of expression. The freshness comes particularly from the fact that the polarized discourses cause an up-to-date specific situation to stand out, which is related to its technological advance: the reports arrive faster, from everywhere, in various ways and in different forms. It is very probable that never before in the West - at least from the Brazilian perspective - a strongly expressive presence of a media born on that other side was noticed. In other words, Al Jazeera invaded, with all its local power and in the same real time as the other networks, the media space previously dominated more easily by the United States.

Its arrival with such strength and speed makes us face the fact that each discourse, in its own way, concomitantly wants to present itself as truer than the other. Both discourses anchor themselves vehemently to the supposed legitimacy either of the one who speaks or of the place from where he speaks. In this way, the simultaneity of these discourses' exposure - discourses that reach us through the media discourses - is fundamental for us to understand 
that the clash reaches its climax, reducing the discourse to its will to truth, a procedure that is exacerbated in response to the strife for the occupation of media space.

Besides this polarization, the reports arrive from many places and in various formats: news blogs with a personal stamp and slanted information, belonging to citizens of the invader and invaded countries, which report the facts from the perspective that is more convenient for them; feature films, documentaries and cable TV programs that try to narrate the facts differently from what we receive from the official media; other printed media, including books, that reveal stories not mentioned by the major newspapers; texts many times found in the so-called top-level press that in extreme situations makes space available for various forms of description of the daily routine. Therefore, this pulverized and polarized discourse, by making explicit the will to truth as a trademark of media discourse, leads us to question truth itself, making us doubt the legitimacy of the and the discoursing places and subjects which obtrude in the media discourses. Furthermore, it is from this perspective that we raise the issue of differences in such narratives.

When discussing "the challenge of going towards the other" on the writing of the documentaries, Guimarães e Lima (2007: 154) suggest that one of the foremost gestures to understanding regards the need to "abandon the I as a way to know the Other". It is necessary to "decentralize it radically, to accord the Other the priority so far granted to the I". From this viewpoint, MV Bill, by presenting himself as a legitimate speaker of the slum and letting us know it through a narrative structure that reflects his view, provides a revealing gesture: what is presented there is the will to truth of his discourse, which makes any encounter with the other unfeasible in the representation context.

In the specific case of this narrative, the discourse in the first person does not reveal a problem merely because it is based on a first-person perspective, but also because other discourses are linked to it, trying to explain, in a shallow encyclopedic tone, what the drug business is - analyzing entries and notes, for example, as to what is meant by a "fogueteiro" and what crack cocaine really is, - giving indicative information that is in turn associated with images that tell us how to see the characters. In addition, through the camera of Falcão..., the children involved 
in the illegal drug business are shown either from above or from below. The camera is rarely placed on the same level as the children, unless it aims at showing their blindfolded eyes and blurred faces. In this manner, the perspective appears to be merely "content-based", as if the accounts we hear and the scenes we see do not belong to the film script; they were framed there and they describe but do not define the events.

In this sense, the film script of Falcão..., as a mirror, reflects the mediatic scenario that we want to understand: the various I's, that in the explicitness of the discourse's will to truth make the dialogue unfeasible and reverberate an ampler situation based on the micro-space of the narrative: they are various voices, or a cacophony if we wish; the reverse of the polyphonic dimension (BAKHTIN) minimally necessary for us to evoke a hypothesis of a practice of othering. From the point of view of the reflection concerning journalistic discourses, which are very much anchored in the presupposition that they are the possessors of truth, the social and technological situation nowadays renews our conditions for reflection: what the polarization and pulverization of the discourses really reveal to us - in the macro-space of media and the structure of many of its narratives - is that if everything is the will to truth, truth or even non-truth, can be in various places and in various discourses.

\section{VEILING AND PRODUCTION OF DIFFERENCES}

There is another troublesome element: the technological advances we experienced with extreme force and speed in the 20th century have led us to be placed at the mercy of the machines. Surrounded by a secular imaginary based on progress and the ordering of the world, we live in search of facilitating formulas to help us apprehend the world in a simple manner; we want to have the world explained rather than made problematic. In this sense, technology - particularly with its image-producing apparatus - plays a central role. Vilém Flusser draws attention to the fact that technical images interpose themselves between man and the world, working in fact as folding screens. For the author, "man, instead of resorting to images based on the world, ends up living based on the images. He no longer deciphers the image scene as the world's significations, but the world itself starts to be 
experienced as a group of images" (2002: 09). This observation questions the fact that images produced by machines fulfill in a certain way the function of explaining the world to us, serving as facilitating objects; as we see what is "said" by the images, we believe that the world is truly represented there ${ }^{6}$.

Once more the documentary Falcão... is a very good example: the set of voices and images that intend to explain to us the drug business dilemmas, besides approaching our "illiteracy", as Flusser would say, cuts and divides life in a slum, hindering us from making the sharing gesture. What we see and hear are scenes that only in their desire for transparency offer answers to our dilemmas, as occurs many times in journalistic discourse, which in the light of a similar explanatory order is predominantly based on statistics and numbers. It is not a matter of thinking in this way about the entire journalistic production, but in general terms it is important to consider the dominating epistemological scheme in this field, its casualty numbers, its generalized definitions, its process of labeling people and things, which simplify complex problems and greatly contribute to the conception of a world that appears to be likely to be put in order and yet impossible to be shared.

The texts and images produced under the aegis of this episteme encounter their motivation and reason for existing in the idea that the purer and more exact the information in them is, the closer to communication they will be in their reports. It is truly a matter of a quantitative dimension; there is not any questioning regarding the quality of the information, but regarding the volume of information (novelty) contained in the report and how fast it reaches the consumer. These media objects are produced with the intent of getting the closest they can to the reality of the object represented, with the certainty that in this way they will tell the truth, the primary presupposition of the will to truth that is established in them. This aspect also explains the fact that the perspective of having an "other" to whom one ought to speak is practically annihilated. Flusser, on thinking about photographic apparatus, says that this narrative "is programmed to be distributed to an empty space, like what is done by television and radio" (2002: 46), in which category we could certainly include newspapers. An "empty space" occupied by a shapeless group to which and about which the media products speak, a space where 
all differences are veiled as if they were dead and, at the same time, as if they could be erased.

This process of veiling the differences, considering the historical, social and cultural idiosyncrasies of the present day coexists with another, also generated by the polarization and pulverization of the places and discourses: the process of production of differences. When one narrates the day-to-day of the slums, for example, from the perspective of such differentiated voices and places, we are induced to be attentive to the fact that the categories defined to explain the logic that governs the formatting of the texts and the technical images need to become more fluid, at the risk of preventing us from ever speaking to the other again. In this, especially, it is worth turning our attention to what Guimarães and Lima say (2007: 149) regarding the difficulties of encountering the other in such representation: "[they] increase exceptionally when it is a matter of filming the other from a different class, the ones who belong to a social group beyond (...) the edge of the visible sphere".

Hence, profiling voices and scenes that are propagated in default of the other is a mere stimulus for the production of differences, since it is important to remember that the search for truth (Foucault, 1996) is still at stake. In other words, the one who speaks through the media continues to be the one that is believed to be the more legitimate speaker, and what occurs in these cases is the alternation of roles or powers in the mediatic space, because the one who speaks is always an "I" who discredits the other. Therefore, we believe that the difference produced in that discourse is purely an effect, as well as the truth that it relies on. In this context, it is worth noting that the process of production of differences, which does not result in a relation of othering, is simply part of the logic of later-day capitalism - a time when information- and knowledge-producing machines achieve primacy. Thus, it is in this scenario that while it is important to know what the discourse says, it is fundamental to investigate what it does.

\section{THE STAGING OF THE NEWS: THE LIBIDINAL POWER}

It is from a challenging perspective and within a cultural approach that it seems to be possible to recognize the complex dimension in which mediatic discourses are inscribed as 
instances for producing meaning. Cultural Studies represent an effort to lead thinking in directions pointing more to the daily routine and to the culture. However, in order not to run the risk of becoming limited to a cultural approach that would neglect the relation between culture and political economics, it is necessary to redefine the role of the critical theory of culture in accordance with the logic of later-day capitalism and the roles played by the media in contemporary society. For Santiago de Castro-Gómez (s/d: 03), "the starting point for Cultural Studies is (...) the devices with which the symbolic welfare (culture) is produced and offered to the public as a commodity".

This aspect makes us redouble our attention, since with it we encompass the idea that the images and texts we produce, including the journalistic ones, are fully representations of ideology and culture ${ }^{7}$. And in this sense, according to CastroGómez, the media are ideological apparatuses that have an advantage over the others, for "their subjection devices are much less coercive". According to the author, "within them there does not circulate a power that 'disciplines and punishes', but a power that seduces". In this aspect, beyond the disciplinary power of modernity, criticized by Foucault, Castro-Gómez says that we would be now "facing the libidinal power of globalization" (s/d: 14). Considering that the reading we make today of the mediatic products depends largely on the way the news is staged, CastroGómez says (s/d: 16):

\footnotetext{
The war of images about a war will be won by the group that, aiming to imprint meaning, best utilizes the libidinal power, in other words, by that group that sets out all the seducing mechanisms of the image to obtain the non-coercive consent of the consumers.
}

Therefore, given the devices which we make use of to stage the news, we perceive that in the war of images involving the drug business and/or the slum, the exclusive view of one who claims to be an expert in that reality may even be seductive, but in the ambit of the representation of differences it becomes configured in a reduced manner, less attentive to the polysemy in which life itself is inscribed, in a slum or in any other place. We even dare to suggest that from the perspective of these images that reduce reality, the script in default of the other leads to the libidinal, the coercive aspect itself, for they are images that impose on us a 
unique order. In Falcão..., even though it is announced to us that we will be introduced to the drug business reality through the eyes of one who lives it, we discover that what prevails is the view of one who trims and produces the images we see.

A second aspect that Guimarães and Lima (2007: 154) point out as fundamental when dealing with the ethical field of representation of the other in documentaries concerns the need to "promote the disjunction between the image and the text, and by assuming that speaking is not seeing, set the image free either from the visible or the invisible". In Notícias de uma guerra particular, we have access to a juxtaposition of images and testimonies that do not complete each other, since they are contradictory, but that interpenetrate one another, because they weave a complex network of lives involved in the slum and the drug business. To the experiences reported to us by the minors, the police chief, the military policemen, the families involved in the drug business and also the very media, which in a meta-discursive dimension are also revealed as a character, images of the so-called war itself, or of the "movimento 21 ", and images of children at play in the streets and people walking home or going to work are added. With the practice of this narrative weaving, there is no contraposition between right and wrong, or good and evil, but it is a form of narration which constantly seems to put in doubt either the speech or the image; in such a narrative one does not say necessarily what will be offered to be seen, as well as one does not show exclusively what the speech says.

Alba Zaluar confirms our view revealing some of the incoherence in what is said in MV Bill's documentary. "Without presenting new information", according to her, "Falcão... casts a tender look on the little drug dealers, but submerges itself in the ghetto culture and ignores the rest of the social actors present in 'Notícias de uma guerra particular'". Therefore, by comparing the two products, we realize that the news staged from such an angle leaves adrift other angles that also could be significant in making the problem understood. In Notícias..., João Moreira Salles, who does not appear to be someone who has lived in a slum, by approaching the theme from the perspectives of the policemen and the criminals, shows us that "there are many voices, many actors in the drama", says Zaluar.

The various products involving slums, among them the 
various blogs, documentaries, printed reports and films about daily particular wars - the small great wars that we are impelled to experience today - say first of all that there are various ways to narrate the events. Hence, we understand that once the news becomes a post-industrial product, knowing what happens in the slums is not enough, since one should also know the ways there are to speak about them, instances in which various voices and various meanings could at times be revealed.

\section{JOURNALISM AND MEDIATIZATION OF DISCOURSES}

Journalism, which we believe to be the place of confluence of voices and production of meanings, seems to be significant in the contemporary context since it helps us understand that informing or producing images and texts in the discourses, whose internal procedures are ruled by the classification of the information, means giving ideological and cultural forms to the preexisting facts a relevant observation that needs to be questioned and contextualized in the space where journalism is inscribed. Flusser (2002: 49), upon considering the process of classifying information, helps us to understand this problem: "every scientific indication" - in which category journalistic information fits perfectly - "has political and esthetic aspects; every political imperative has scientific and esthetic aspects; every optative gesture (work of art) has scientific and political aspects".

With the problematics therefore expanded, it is important to emphasize that it is necessary to recognize that the political place of journalistic discourses is not dissociated from the esthetic, which is established in them and to which they are subjected. The aggravating element is the fact that nowadays coercive power is connected to a libidinal power - the seducing gesture can also be excluding. This fact, besides being a strong indicator that the space for the expansion of the discourse does not necessarily mean democratization of the discourses, maintains us as hostages of those who know how to better produce the images and the texts. Thus, working from the perspective of a possible differentiation of the narrations, at the same time that it makes us think about the journalism statute in times of extreme mediatization of events, it might lead us to produce or point out distinct strategies: are there narrations that, with the intention of explaining the facts, seek totalizing truths? Are there others that 
point to a more complex dimension?

According to Michel de Certeau (2000), alterity does not consist of speaking of the other in the text, but of being aware of the other through what the script says without meaning to say it. MV Bill, besides being the film's director of Falcão - os meninos do tráfico, is a rapper, which probably caused the film's background music to be a rap. Again, another comparison with Notícias de uma guerra particular can clarify our view: in this documentary, rap music is also played, though not as background music but as part of the script itself. In one of the scenes, the testimony of one of the drug dealers is absolutely connected to the music, either by the rhythm of his utterance or by the use the character makes of his words. Therefore, the reported event - life and the drug business in the slum - is imbricated with inter-texts that help us to comprehend the complexity and the structure of this event.

For Correia (s/d: 14), the search for a balance or "quality", as the author says, in the language practiced in the journalistic field, can signify a "return to the text in search of the enunciative marks". Definitely, even if it is relevant to question whether the wars - of the drug business or of any other nature - will be the subject matter for today's newspaper, before the processes of veiling and producing differences, it is not less important to try to find the ways and the places in which these discourses will occur. The technological advances that exacerbate the production of narratives and make the plurality of ways to narrate the events of the daily routine stand out, should make us attentive to the perspective that there are narratives that supply the world with differences, while there are others that do not; there are some that reject the particularities and still others that emphasize them; there are others that speak of a place in motion and some that narrate the world as something static.

In the representation's dimension, everything seems to indicate that one can better confront the dilemma of encountering the other by recognizing the difference between these narrations. In various ways, since what is brought to the scene is the will to truth itself, rediscovering news in its esthetic dimension can contribute to making us become concerned, not necessarily because we want to keep on searching for truth, but probably because we want to know the various angles of the problem. In this situation, we alter the focus, as what is in question is the truth of the event, not the truth of the one who speaks about it. 


\section{NOTES}

1 In this article, for space reasons, the studies with a positivist paradigm are being dealt with in a generalizing manner. The reflection on journalism studies, in its hegemonic perspective, is better developed in RESENDE (2002).

2 Ramos (2005) identifies 3 distinct ethical fields referring to the representation of the other in documentary film production. Our reflection aims to explore the problematic raised by this author, discussing the same issue from the perspective of the production called "journalistic".

3 In http://www1.folha.uol.com.br/folha/ilustrada/ult90u59234.shtml (accessed 5/23/2008).

4 Flusser (2002) classifies the information contained in discourses as indicative, imperative and optative. The first one, for the author, is the classification of the so-called "journalistic information" and has truth as its classical ideal. It is also interesting to note that this information classification leads us directly to what is said by Foucault (1996) in relation to the procedures of exclusion, which are within the discourse; this is the case of the media products specifically dealt with in this article.

5 Flusser (2002) bases his ideas on our historical and cultural conditions to make an interesting reflection regarding the presence of images in the contemporary world. For the author, "traditional images - the cave paintings - seek to imagine the world, and when these images fall into a crisis, written texts, the founders of modern chronological history, arrive to carry out the function of explaining the images that used to imagine the world".

6 For Santiago de Castro-Gómez (s/d: 14) "the expansion of the concept of ideology (...) can be of great value for the understanding of how images, figures and symbolic narratives (...) built representations that serve to reinforce the domination of some groups over others. These ideological representations are not (...) unitary, as Althusser used to think at first. Through the media not only the major political and economic ideologies are built, but also ideologies of gender, race, sexuality and social position that are not necessarily reducible to each other". This reflection can 
be added to APPADURAl's (2003), who sees images and texts as fundamental social representations for building meaning in the contemporary world.

\section{REFERENCES}

APPADURAI, Arjun. Modernity at large: cultural dimensions of globalization. Minneapolis: Univ. of. Minnesota Press, 2003.

BAKHTIN, Mikhail. Marxismo e filosofia da linguagem. São Paulo: Hucitec, 1979.

BENETTI, Marcia. Análise do Discurso em Jornalismo: estudos de vozes e sentidos. In: LAGO, C. \& BENETTI, M. (eds.). Metodologia de Pesquisa em Jornalismo. Petrópolis: Vozes, 2007.

BENVENISTE, Émile. Problemas de Lingüística geral. 4.ed. Campinas: Pontes, 1995.

CASTRO-GÓMEZ, Santiago. "Althusser, los estúdios culturales y el concepto de ideologia", available in http://www.javeriana.edu.co/pensar/Alt.html acesso: june 2006 .

CERTEAU, M. A invenção do cotidiano. Petrópolis: Vozes, 2000.

CERTEAU, M. A escrita da história. Rio de Janeiro: Forense Universitária, 2002.

CORREIA, João Carlos. Linguagem jornalística, estranheza e referência. http://www.bocc.ubi.pt/pag/correia-joao-linguagem-jornalisticaestranheza-referencia.pdf. Acesso: julho 2007.

FLUSSER Vilém. A filosofia da caixa preta: ensaios para uma futura filosofia da fotografia. Rio de Janeiro: Relume Dumará, 2002.

FOUCAULT, Michel. A ordem do discurso. São Paulo: Loyola, 1996.

GUIMARÃES, C. \& LIMA, C. A ética do documentário: o Rosto e os outros. Revista Contracampo, Niterói, UFF (2007/2).

RESENDE, Fernando. Ausências na Comunicação Social e no Jornalismo: a 
lógica da rua. Oficina do CES. Coimbra: Centro de Estudos Sociais, 2003 (www.ces.uc.pt/ Oficina n.197)

RESENDE, Fernando. O olhar às avessas: a lógica do texto jornalístico. São Paulo: ECA/USP, 2002 (tese de doutoramento).

SANTOS, Boaventura de Sousa. Os processos da globalização. In: SANTOS (org.) Globalização: fatalidade ou utopia? Porto: Afrontamento, 2001, p.31-109.

TUCHMAN, G. A objectividade como ritual estratégico: uma análise das noções de objectividade dos jornalistas. In: TRAQUINA, N. (org.). Jornalismo: questões, teorias e "estórias". Lisboa: Veja, 1999.

FERNANDO RESENDE is a professor at Federal Fluminense University (UFF). He holds a PhD in Communication Sciences from São Paulo University (USP), and a post doctorate degree from the School of Oriental and African Studies at the University of London. 